PAIDIA - ŻYWIOŁ DZIECIŃSTWA 



\title{
Pochwała Koziołka Matołka, czyli o mądrości literatury dla najmłodszych
}

\begin{abstract}
The article attempts to reread the canonical work of Polish children's literature. It perceives its protagonist, Koziołek Matołek, as a sage and insightful observer of the world, whose disguise of a fool allows him to distance himself from it. Hence, Przygody Koziołka Matołka [The Adventures of Matolek the Billy-goat] might also serve didactic purposes when it comes to the young readers in the $21^{\text {st }}$ century; these might learn from it how to laugh at themselves or dissociate from problems, which are indispensable qualities regardless of the times we live in.
\end{abstract}

Keyword s: Koziołek Matołek, Matołek the Billy-goat, Kornel Makuszyński, humour

Koziołek Matołek, bohater książki Kornela Makuszyńskiego, powszechnie uważany za zabawną postać, w rzeczywistości jest mędrcem, wszak w każdej sytuacji bez względu na to, czy jest ona groźna, niemiła czy absurdalna, potrafi otworzyć furtkę do krainy uśmiechu i wprowadzić przez nią wszystkich czytelników bez ograniczeń wiekowych, płciowych oraz związanych z wykształceniem czy ze stanem cywilnym. Zawsze robi to z taktem, kulturą (nigdy nie używa wulgaryzmów) i wdziękiem, nierzadko okraszając swe zaproszenie aforyzmem, z których najpiękniejszy jest ten wieńczący książkę:

\footnotetext{
Opowiedział im dokładnie mądrze, jak to miał w zwyczaju, I tak skończył: „Wszędzie dobrze, lecz najlepiej w własnym kraju”. Makuszyński, 2010, s. 64
}

Nie oznacza to, że Koziołek Matołek jest nacjonalistą. Choć podróżował dużo i z pasją, zaprzyjaźniał się ze wszystkimi napotkanymi po drodze (może poza krokodylem, ale któż z nas miałby ochotę na taką przyjaźń!), zachwycał się oglądanymi pejzażami, fascynowały go cudze obyczaje i z łatwością je przyswajał, to 
zawsze wracał do kraju i nadwiślański pejzaż witał z radością. Sam autor, Kornel Makuszyński, z uznaniem pisze o swoim bohaterze, komplementującymi epitetami podkreślając jego rozumność i idące $\mathrm{z}$ nią $\mathrm{w}$ parze intelektualne atuty, a Marian Walentynowicz solennie ten podziw ilustruje.

Aby nie pozostać gołosłowną, wypada podać kilka przykładów. Naszego Koziołka w świat wysyłają „Wszystkie mądre polskie kozy” (s. 5), bo jak sam autor go określa, to przecież „koziołek - mądra głowa” (s. 27) czy „Wielce mądry nasz Matołek” (s. 84), którego intelekt doceniają zwierzęta z Afryki: „jesteś strasznie mądry" (s. 36). Matołek dzięki niepośledniej inteligencji wygrywa konkurs z Krwawym Bizonem, bo „w mądrej głowie szukał rady” (s. 43), a gdzie indziej dowiadujemy się, że „głowę miał na karku” (s. 80) i „nie był w ciemię bity” (s. 44). O powszechnym uwielbieniu dla tej postaci zaświadcza cytat: „O, Koziołku - wszyscy krzyczą - wszystko zrobić sam potrafisz” (s. 80).

Koziołek ma typową, by użyć określenia Henriego Bergsona, fizjognomię komiczną, i już ona sama $\mathrm{z}$ jednej strony budzi sympatię, ale $\mathrm{z}$ drugiej - czasem zwodzi, zwłaszcza tych, którzy posądzają go o naiwność; takie osoby może łatwo wyprowadzić w pole. Matołek na ogół ma dobre samopoczucie i w każdej sytuacji akceptuje siebie. Jest dzielny, bo podjął ryzyko podróży w nieznane, i to każdy musi przyznać. Mecząc, jest przekonany, że śpiewa piękniej niż słowiki, a powołany do wojska, z dumą zauważa, ujawniając przy tym świadomość historyczną, że „tak zaczynał Bonaparte”.

Jest absolutnie piękny, i to nie tylko dzięki talentowi Mariana Walentynowicza, lecz z przyrodzonej koziemu rodowi urody. Jego piękno podkreślają szlachetna broda, majestatyczny krok: „Kroczył śmiało, beczał ślicznie / z bardzo dumną pańską miną” (s. 45), oraz sztuka wymowy — „wygłosił piękną mowę” (s. 45).

Ponadto Matołek jest bardzo dobrze wychowany oraz uprzejmy dla ludzi i zwierząt, może się pochwalić dużym obyciem towarzyskim. I tak, z kaczką rozmawia po francusku, grzecznie pytając o zdrowie, z cesarzem chińskim po chińsku, a z Hindusami po „indyjsku”. Posiada też spory zapas stosownych złotych myśli na każdą okazję: „Niech ogony wam odlecą” — powie pobladły i zirytowany do małp, chcących go uczynić swoim królem, a przemieszczając się z księżyca na ziemię na spadającej gwieździe, choć przerażony woła „raz śmierć kozie!”, to jednak nigdy nie klnie.

Jego sława obiegła prawie cały świat - Koziołek nie dotarł do Związku Radzieckiego, choć nosił czerwone spodnie (Heska-Kwaśniewicz, 2003, s. 13) - dlatego nie dziwi fakt, że bogaty mandaryn chce go usynowić, a małpy, jak wiadomo, pragną go swym uczynić królem, z kolei słoń wita go słowami: „Witaj nam, szlachetny Panie” (Makuszyński, 2010, s. 76), a ktoś inny w pełen atencji sposób pozdrawia: „Dobry Panie, cny Matołku” (s. 73). Matołek jest wszędzie oczekiwany i pożądany. Afrykańskie zwierzęta w liście piszą: „Więc przybywaj do nas prędko, sławny koźle sponad Wisły" (s. 73), natomiast Beduini spotkani na Saharze witają go apostrofą: „O szlachetna polska kozo” (s. 83), ponieważ obyty 
w świecie i dobrze wykształcony Matołek wcześniej pozdrowił ich słowem „Salem", natychmiast zyskując przychylność gospodarzy. A gdy w Turcji zaczyna być głośno o tym, że przybył kozioł z Lechistanu, czytelnik dowiaduje się o legendarnym pochodzeniu Koziołka i tureckiej przychylności oraz szacunku dla Polski.

Zresztą zanim Matołek się gdzieś pojawi, to poprzedza go swego rodzaju sława literacka: „Idzie ten, o którym książki / pisze Kornel Makuszyński” (s. 86). Jeśli pisze o nim autor wybitny, tłumaczony na języki obce oraz znany w Polsce i na świecie, to najlepiej świadczy o wielkości bohatera i stanowi jego prawdziwą nobilitację.

Wszystkie głupstwa Koziołek popełnia z ogromnym wdziękiem, ma niepospolitą wyobraźnię, młodzieńczą ciekawość świata i dziecięcą wrażliwość, która prowadzi do bogactwa skojarzeń, oryginalności i śmiałych obserwacji. Czytelnicy oglądają świat oczyma Koziołka, a on pokazuje każdą rzecz z dwóch stron: koziej i ludzkiej, wielkiej i małej, dobrej i złej. Zwykle ludzka wypada gorzej. Ale ten dualizm spojrzenia pozwala Matołkowi obnażyć przed czytelnikami absurdalność świata urządzonego przez człowieka, ośmieszyć wzniosłość „ludzkiej” hierarchii: urzędów, stanowisk, godności, zawodów. Ilustrator, „przymierzając" je niejako do koziej postaci, tworzy karykatury, a pisarz jeszcze bardziej pogłębia to wrażenie, dopisując dowcipny komentarz. Ileż absurdalnych praw pojawia się w tej książce, np.:

Przyszedł do jednego miasta,

Gdzie wydano prawo nowe:

„Kto by z brodą wszedł na rynek,

Temu zaraz utną głowę!”.

Takie prawa, w książce, a często i w życiu przestrzegane w sposób bezwzględny, są krzywdzące i nieludzkie. Ośmieszone zostają także zawody cieszące się powszechnym poważaniem. Tak też jest np. z omnipotencją lekarską, której „uwieńczeniem” jest głęboka refleksja: „Gdy nie umrze, to żyć będzie!”.

Matołek jest ostrożny i zaskakuje tych, którzy przypisują mu naiwność. Niedźwiedziowi zapraszającemu go w ZOO do swojej klatki odpowiada protekcjonalnie:

Tere fere - rzekł Koziołek

- Sam się podrap, mój ty zuchu,

Bom ja wcale nie ciekawy,

Jak się siedzi w twoim brzuchu.

$$
\text { s. } 56
$$

Lisa i papugę pomijamy, te zwierzęta zachowały się po prostu niegodnie wobec Koziołka. Potrafi on również przechytrzyć i kupca, i wojskowego zwierzchnika, gdy na polecenie obcięcia brody odpowiada: 
Ja nie jestem taki głupi

I dam obciąć nadmiar brody,

Lecz niech przedtem ktoś ją kupi.

s. 54

Koziołek lubi się popisywać swoją mądrością, a możnym tego świata chętnie zadaje absurdalne zagadki (np. królowi murzyńskiemu), chytrym fortelem wyprowadza w pole chińskiego cesarza i sprytną ucieczką salwuje się z ogrodu zoologicznego. Cieszy się wtedy jak dziecko, któremu udało się zakpić z dorosłych. Podobnie jak wtedy, gdy zdobywając wszystkie zaszczyty, przejawia wobec nich pobłażliwy stosunek. Może dlatego tak łatwo przychodzi mu rezygnacja $\mathrm{z}$ „posady" małpiego króla, a może to raz otrzymana nauczka przekonała go na całe życie o szkodliwości pychy. Przykładem jego zaskakującej logiki jest przygoda w wojsku:

„W tył zwrot!” - głośna brzmi komenda.

Wszyscy odwrócili pięty,

Tylko nasz Matołek nie drgnął

I wciąż stoi uśmiechnięty.

"Czemu stoisz?” - zakrzyknęli,

A Koziołek odrzekł mile:

„Ja nie jestem wcale ciekaw,

Co się za mną dzieje w tyle".

„Padnij!” - nowa brzmi komenda.

Wszyscy czynią to z ochotą,

A Koziołek w śmiech i rzecze:

„Przecie tu jest mokre błoto!”.

Zanim więc wykonamy polecenie zwierzchnika, zapytajmy go „dlaczego?”, „czemu to ma służyć?", a uchronimy siebie i przełożonego przed niejednym kłopotem.

Z dramatycznych sytuacji Koziołek wyprowadza zabawne wnioski, a groźne zbiegi okoliczności łagodzi pogodną radością, zło przemienia w dobro, ponieważ jego żart „szczypie, a nie kąsa”. Grozę oraz napięcie rozładowują wprowadzane przez autora niezwyczajne wydarzenia, porzekadła, zwroty akcji czy komiczny rysunek połączony $\mathrm{z}$ opisem nielicującym $\mathrm{z}$ charakterem ilustracji. Tym samym Makuszyński uczy kultury humoru, jego żart jest zawsze w dobrym guście, nigdy nie przekracza cienkiej linii dobrego smaku, nigdy nie jest wulgarny, kształtuje takie patrzenie na świat, które pozwala dostrzec jego śmieszności oraz szukać okazji do uśmiechania się i rozładowywania niszczącego napięcia. 
Czerwone i czarne Stendhala lub Komu bije dzwon Hemingwaya możemy przeczytać, mając dwadzieścia pięć lub trzydzieści lat. Prawdopodobnie taki sam pożytek odniesiemy z tej lektury. Jeśli jednak we wczesnym dzieciństwie nie poznamy Przygód Koziołka Matołka, to już przez całe życie pozostaniemy pryncypialni i bez poczucia humoru.

\section{Literatura}

Bergson H., 2000, Śmiech. Esej o komizmie, S. Cichowicz, przeł., Warszawa.

Heska-Kwaśniewicz K., 2003, Koziołka Matołka bój ze stalinizmem, „Tygodnik Powszechny" nr 33.

Makuszyński L., Walentynowicz M., 2010, Przygody Koziołka Matołka, Poznań.

Krystyna Heska-Kwaśniewicz - profesor doktor habilitowany nauk humanistycznych, profesor zwyczajny w Instytucie Bibliotekoznawstwa i Informacji Naukowej Uniwersytetu Śląskiego w Katowicach. Badaczka polskiej literatury dla dzieci i młodzieży, znawczyni polskiego życia literackiego na Śląsku, monografistka Gustawa Morcinka, wieloletnia redaktorka rocznika „Śląskie Miscellanea”. Ważniejsze publikacje: Braterstwo i stużba. Rzecz o pisarstwie Aleksandra Kamińskiego; Taki to mroczny czas. Losy pisarzy ślaskich w okresie wojny i okupacji; Ludzie - góry - książki.

e-mail: canes@o2.pl 
